\title{
Effects of selective estrogen receptor agonists on estrogen receptor expression in the uterus of ovariectomized rats
}

\author{
C. S. Blesson, Britt Masironi, Lena Sahlin*
}

Division for Reproductive Endocrinology and the Pediatric Endocrinology Unit, Department of Women's and Children's Health, Karolinska Institutet, Stockholm, Sweden

Email: *lena.sahlin $@$,ki.se

Received 19 January 2012; revised 6 March 2012; accepted 3 April 2012

\begin{abstract}
The aim of the present study was to investigate effects of short time treatment with estrogen receptor (ER) selective agonists on ER $\alpha, E R \beta$ and G-protein coupled estrogen receptor-1 (GPER) expression in the uterus of ovariectomized rats. The rats were treated with either estradiol (E2), the specific ER $\alpha$ agonist PPT or the specific ER/ agonist DPN for $18 \mathrm{hrs}$. Uterine weights were higher after E2 or PPT treatment than after DPN or no treatment. ER $\alpha$ mRNA levels decreased significantly in PPT and DPN treated animals as compared to controls. Stromal ER $\alpha$ immunostaining was higher after $\mathrm{E} 2$ treatment than in controls. The ERß mRNA level was lower in the E2 and PPT groups compared with controls. ER $\beta$ immunoreactivity was higher in the myometrium after DPN treatment than in controls. The GPER mRNA level was lower in the E2 and DPN groups as compared to the controls, whereas total protein levels did not display any change. The proliferation marker Ki67 increased after PPT treatment in stroma and myometrium, as compared to controls. Thus, uterine growth and proliferation are predominately regulated via ER $\alpha$. Also ER $\beta$ expression showed regulation via ER $\alpha$, while GPER expression indicated control via ER/. This short term treatment did not result in any regulation of the total protein level as determined by Western blot. However, treatment by $\mathrm{E} 2$ increased ER $\alpha$ immunostaining in the stroma and DPN augmented ER $\beta$ immunostaining in the myometrium. Thus, the estrogen receptors in the rat uterus are differently regulated depending on the ligand and tissue type.
\end{abstract}

Keywords: PPT; DPN; ER $\alpha$; ER $\beta$; GPER

\section{INTRODUCTION}

Estrogen and progesterone provide the basis for the cy-

"Corresponding author. clic changes in the uterine tissues during the estrous cycle. The action of estrogen is primarily mediated via binding to specific intracellular receptors in the target cells. The estrogen receptors (ER) are members of a superfamily of nuclear transcription factors with highly homologous DNA binding and ligand binding domains [1-5]. After the discovery of the $\beta$ subtype [1], the hormonal signals are now assumed to be transduced by both $\mathrm{ER} \alpha$ and $\mathrm{ER} \beta[1,3,4]$. Both ERs bind estradiol (E2) with high affinity and specificity [6]. Although ER $\beta$ shares many functional characteristics with $\mathrm{ER} \alpha$, the molecular mechanisms regulating the transcriptional activity and the tissue location of $\mathrm{ER} \beta$ are distinct from those of ER $\alpha$ $[1,6]$. In ovariectomized rats, E2 induces DNA synthesis and mitosis in the uterus, whereas progesterone inhibits DNA synthesis in the epithelium, but stimulates mitosis in stromal cells $[7,8]$. ER $\alpha$ turns on target gene expression and functions as a regulator of ligand-activated transcription in estrogen responsive tissues [9].

The membrane bound estrogen receptor G-protein coupled receptor-30, now denoted G-protein coupled estrogen receptor-1 (GPER), has been described and studied intensely during the last decade [10-15]. GPER seems to be of great importance for several metabolic functions in the female mice as found by studies in GPER knock-out mice, while no effect on the reproductive tract, e.g. uterine weight, was found [13]. The uterine weight increased in GPER -/- mice after treatment with E2 [16]. There has been studies claiming that GPER has no effect in the female reproductive tract [17], but also that GPER is a factor of poor prognosis of endometrial cancer [18]. Recently an article describes that GPER activation opposes estrogen dependent uterine growth via inhibition of phosphorylation signals [19], indicating why GPER still could have importance in the female reproductive tract.

The non-steroidal compounds PPT and DPN $\left(4,4^{\prime}, 4^{\prime \prime}-\right.$ (4-Propyl-pyrazole-1,3,5-triyl) trisphenol and 2,3-bis(4hydroxyphenyl)-proprionitrile, respectively) are characterized as selective agonists for $\mathrm{ER} \alpha$ and $\mathrm{ER} \beta$, respectively. PPT is approximately 1000 -fold more potent as an 
agonist on $\mathrm{ER} \alpha$ than on $\mathrm{ER} \beta$ and has a 400 -fold preference towards ER $\alpha$ in its binding affinity [20,21]. DPN has a 70 -fold higher relative binding affinity and 170 -fold higher relative potency in transcription assays with ER $\beta$ than with $\mathrm{ER} \alpha$ [22]. None of the compounds are known to bind GPER. $17 \beta$-estradiol (E2) has equal affinity $\left(\mathrm{K}_{\mathrm{d}}\right.$ approx. $0.1-1 \mathrm{nM}$ ) for $\mathrm{ER} \alpha$ and $\mathrm{ER} \beta$ [6], and a little less $\left(\mathrm{K}_{\mathrm{d}}\right.$ approx. $\left.6 \mathrm{nM}\right)$ to GPER [11].

The aim of the present study was to determine the distribution of ERs, also regarding subtype, in the rat uterus after short term treatment with selective estrogen receptor agonists. We have studied $\mathrm{ER} \alpha, \mathrm{ER} \beta$ and GPER expression and immunostaining in the uteri of ovariectomized rats treated with an ER $\alpha$ agonist (PPT), an ER $\beta$ agonist (DPN) or E2. In addition, uterine growth and the proliferation marker Ki-67 were monitored.

\section{MATERIAL \& METHODS}

\subsection{Animals}

Thirty female adult Sprague-Dawley rats, 55 - 60 days old and weighing approximately $250 \mathrm{~g}$ were used. The animals were housed in a controlled environment at $21^{\circ} \mathrm{C}$ $-23^{\circ} \mathrm{C}$ on an illumination schedule of $12 \mathrm{~h}$ of light and $12 \mathrm{~h}$ of darkness. Standard pellet food and water were provided ad libitum. The rats were ovariectomized (ovx) during anesthesia with Xylazin (Bayer AG, Leverkusen, Germany; $0.75 \mathrm{mg} / 100 \mathrm{~g}$ rat) and Ketaminol (Intervet AB, Boxmeer, Netherlands; $7 \mathrm{mg} / 100 \mathrm{~g}$ rat). They were housed for 14 days before initiation of hormone treatment. The ovx animals were treated with one single s.c. injection with $5 \mu \mathrm{g}$ E2/rat $(\mathrm{n}=8), 1.25 \mathrm{mg}$ PPT (4,4',4"-(4-Propyl-pyrazole-1,3,5-triyl) trisphenol)/rat $(\mathrm{n}=8)$ or 3.125 mg DPN (2,3-bis(4-hydroxyphenyl)-proprionitrile)/ rat (n $=6), 18 \mathrm{hrs}$ before sacrifice. Ovx animals treated with vehicle $(\mathrm{OvxC})$ served as controls $(\mathrm{n}=8)$. The animal studies were approved by the Committee on Animal Care in Sweden.

\subsection{Hormones}

Estradiol-17 $\beta$ was purchased from Sigma Co. (St. Louis, Missouri), and dissolved in $99.5 \%$ ethanol at a high concentration and then diluted with 50:50 DMSO:PBS to the proper concentration. The final concentration of ethanol was less than $2 \%$ in the injections. PPT and DPN were bought from Tocris Cookson, via Bio Nuclear, Bromma, Sweden.

\subsection{Tissue Collection}

At sacrifice the uterus was removed, stripped of fat and connective tissue, weighed and cut in one half and two quarter pieces. One quarter was immersion-fixed in $4 \%$ formaldehyde at $4^{\circ} \mathrm{C}$ for 8 hours and stored at $4^{\circ} \mathrm{C}$ in
$70 \%$ ethanol and thereafter embedded in paraffin. One quarter of the uterine tissue was stored in $-70^{\circ} \mathrm{C}$ for protein extraction. The rest of the tissue was placed in RNA stabilization solution (RNAlater, Ambion, Austin, TX, USA) immediately after collection and stored at $-20^{\circ} \mathrm{C}$ until analyzed.

\subsection{RNA Preparation and Reverse Transcription}

Total RNA from the uterine tissue of each animal was purified with the RNeasy kit (Qiagen $\mathrm{GmbH}$, Hilden, Germany) according to to the manufacturer's protocol. Two $\mu \mathrm{g}$ of total RNA from each sample was reverse transcribed at $37^{\circ} \mathrm{C}$ for $60 \mathrm{~min}$ in a final volume of $20 \mu \mathrm{l}$ with a reaction mixture (Qiagen $\mathrm{GmbH}$, Hilden, Germany) containing $1 \times$ RT buffer, dNTP mix $(0.5 \mathrm{mM}$ each dNTP), $300 \mathrm{ng}$ random primers (Invitrogen, Paisley, UK), 10 units RNase inhibitor (Superase-In, Ambion, Austin, TX), and $4 \mathrm{U}$ of Omniscript ${ }^{\mathrm{TM}}$ reverse transcriptase (Qiagen).

\subsection{Real Time PCR for ER $\alpha, E R \beta$, GPER and RPLP0}

Real time PCR was performed using cDNAs corresponding to $100 \mathrm{ng}$ RNA either using $10 \mu \mathrm{l}$ of Quantitect $^{\mathrm{TM}} \mathrm{SYBR}^{\circledR}$ Green PCR mix (Qiagen) containing HotStarTaq DNA polymerase, PCR buffer, dNTP mixture and $0.3 \mu \mathrm{M}$ of each oligonucleotide primer in a final volume of $20 \mu$ or $12.5 \mu \mathrm{l}$ of $\mathrm{iQ}^{\mathrm{TM}}$ SYBR ${ }^{\circledR}$ Green Supermix (Bio-Rad) and $0.3 \mu \mathrm{M}$ of each oligonucleotide primer in a final volume of $25 \mu \mathrm{l}$. The samples were subjected to an amplification of 40 cycles. The annealing temperatures were $57^{\circ} \mathrm{C}$ for ER $\alpha, \operatorname{ER} \beta$ and RPLP0, and $60^{\circ} \mathrm{C}$ for GPER. The purity of PCR products was confirmed by a melting curve analysis in all experiments. The oligonucleotide primers for $\operatorname{ER} \alpha, \operatorname{ER} \beta$, GPER and RPLP0 are as follows: ER $\alpha$ (Accession number NM_012689.1) 5'-TACGAAGTGGGCATGATGAA-3' (forward) and 5'-AAGGTTGGCAGCTCTCATGT-3' (reverse); ER $\beta$ (Accession number NM_012754.1) 5'-TATCTCCTCCCAGCAGCAGT-3' (forward) and 5'-CTCCAGCAGCAGGTCATACA-3' (reverse); GPER (Accession number NM 133573.1) 5'-TTCATCAACCTGGCAGCGGCTG3' (forward) and 5'-TGCAGAGCACGGCGATATCGT3' (reverse); RPLP0 (Accession number NM_001002.3) 5'-GGCGACCTGGAAGTCCAACT-3'(forward) and 5'CCATCAGCACCACAGCCTTC-3' (reverse) to yield products of 138, 145, 100 and 149 bp respectively. Each PCR assay included a negative control containing a RNA sample without reverse transcription. All PCR reactions were performed twice for all rats. The values of relative expression of genes of interest were normalized against the housekeeping gene RPLP0, which was selected out 
of several tested housekeeping genes as an invariable internal control.

\subsection{Immunohistochemistry}

Immunohistochemical technique (avidin-biotin-peroxidase) was used to visualize ER $\alpha, \mathrm{ER} \beta$ GPER and $\mathrm{Ki}-67$ immunostaining intensity and distribution. A monoclonal mouse anti-human antibody was used for detection of ER $\alpha$ (08-1149, Zymed Laboratories, Inc., San Francisco, $\mathrm{CA})$. It recognizes the $\mathrm{N}$-terminal domain (A/B region) of ER $\alpha$. A polyclonal rabbit anti-rat ER $\beta$ antibody (PA1310B, Affinity Bioreagents, Inc., UK), which corresponds to the C-terminal amino acid residues 467 - 485, was used for detection of ER $\beta$. An anti-human GPER polyclonal antibody (HPA027052) raised in rabbit was purchased from Atlas antibodies, Sweden. A monoclonal mouse anti-human antibody was used for detection of Ki-67 (NCL-Ki67-MM1, Novocastra Laboratories Ltd, Newcastle upon Tyne, UK). After the tissue sections were dewaxed and rehydrated, an antigen retrieval procedure was performed. Sections were pretreated in a microwave oven at high power, in $0.01 \mathrm{M}$ sodium citrate buffer ( $\mathrm{pH}$ 6.0) for $10 \mathrm{~min}$, and then allowed to cool for a further $20 \mathrm{~min}$. Following washing in buffer $(0.1 \mathrm{M}$ Phosphate buffered saline (PBS), $\mathrm{pH}$ 7.6, for ER $\alpha$, GPER and Ki-67, and $0.1 \mathrm{M}$ Tris-buffered saline (TBS), $\mathrm{pH} 7.4$, for $\mathrm{ER} \beta$ ), non-specific endogenous peroxidase activity was blocked by treatment with 3\% hydrogen peroxide (Merck, Darmstadt, Germany) in methanol for $10 \mathrm{~min}$ at room temperature. The sections were then washed for 10 $\mathrm{min}$ in buffer, and were blocked for $30 \mathrm{~min}$ in non-immune horse serum diluted in PBS for ER $\alpha$ and Ki-67, normal goat serum in TBS containing 5\% (w/v) BSA for $\mathrm{ER} \beta$ and donkey serum diluted in PBS for GPER in a humidified chamber at room temperature. The tissue sections were thereafter incubated with the respective primary antibodies (ER $\alpha 1: 5$, ER $\beta$ 1:1000, GPER 1:150 and $\mathrm{Ki}-67$ 1:200) at $4^{\circ} \mathrm{C}$ overnight.

Negative controls were obtained by replacing the primary antibody with non-immune $\operatorname{IgG}$ of the equivalent concentration. Following primary antibody binding, the sections were incubated with the appropriate second antibody, for ER $\alpha$ and Ki-67: a biotinylated horse antimouse IgG (Vectastain, Vector), diluted in normal horse serum, was used for 60 or 30 min respectively at room temperature; for ER $\beta$ : a biotinylated goat anti-rabbit IgG antibody (Santa Cruz Biotechnology, CA), diluted in normal goat serum, was incubated for $30 \mathrm{~min}$ at room temperature and for GPER: a biotinylated donkey antirabbit IgG antibody (Santa Cruz Biotechnology, CA). Thereafter the tissue sections were incubated for $30 \mathrm{~min}$ at room temperature with a horseradish peroxidase-avidin biotin complex (Vectastain Elite, Vector, CA). The site of the bound enzyme was visualized by the application of 3,3'-diaminobenzidine in $\mathrm{H}_{2} \mathrm{O}_{2}$ (DAB kit, Vector, $\mathrm{CA}$ ), a chromogen which produces a brown, insoluble precipitate when incubated with enzyme. The sections were counterstained with hematoxylin and dehydrated before mounted with Pertex ${ }^{\circledR}$.

\subsection{Image Analysis}

A Leica microscope connected to a computer using Colorvision software (Leica Imaging System Ltd. Cambridge, England) was used to assess ER $\alpha$ and $\mathrm{Ki}-67 \mathrm{im}-$ munostaining quantitatively by a computer image analysis system. Quantification of immunostaining was performed on the digitized images of systematic randomly selected fields of endometrial stroma, from which nonstromal elements (e.g. luminal and glandular epithelium) were interactively removed and analyzed separately. All luminal and glandular epithelia as well as 12 fields of stromal cells were measured separately in each tissue section. By using color discrimination software, the total area of positively stained cells (brown reaction product) was measured, and expressed as a ratio of the total area of cell nuclei (brown reaction product + blue haematoxylin).

\subsection{Manual Scoring}

The intensity and tissue distribution of $\operatorname{ER} \beta$ and GPER immunostained cells were manually evaluated independently by two observers blinded to treatment, using a semi-quantitative manual scoring on a four point scale: $(-)=$ negative,$(+)=$ faint,$(++)=$ moderate and $(+++)=$ strong immunostaining.

\subsection{Protein Extraction}

Uterine tissues were disrupted in ice-cold cell lysis buffer (1:10 tissue:buffer) containing $50 \mathrm{mM}$ Tris- $\mathrm{HCl}, 150 \mathrm{mM}$ $\mathrm{NaCl}, 1 \%$ Triton-X and $5 \mathrm{mM}$ EDTA. Before use 1 tablet protease inhibitor (Roche Complete Mini protease inhibitor, Roche) was added/10 ml buffer. Protein concentrations were measured by Lowry protein assay with BSA as a standard [23].

\subsection{Western Blot}

Uterine samples from all rats were available for western blot. Ten $\mu \mathrm{g}$ of protein extract from each sample were resolved on $10 \%$ polyacrylamide gels (Bio-Rad) in MiniProtean II cell (Bio-Rad) using Tris-Glycine buffers. The proteins from the gel were transferred to a PVDF membrane (Amersham) by electroblotting. After blocking the membranes in $5 \%$ non-fat milk (NFM) in $0.1 \%$ TBSTween (overnight at $4^{\circ} \mathrm{C}$ for $\mathrm{ER} \alpha, 60 \mathrm{~min}$ at $\mathrm{RT}$ for $\mathrm{ER} \beta$ and GPER), they were incubated ( 3 hours at RT for ER $\alpha$ 
and overnight at $4^{\circ} \mathrm{C}$ for $\mathrm{ER} \beta$ and GPER) with primary antibodies (ER $\alpha$ F-10, Santa Cruz, 1:500; ER $\beta$ E1276, Sigma, 1:1000; GPER HPA027052, Atlas, 1:500). Membranes were washed and incubated for $60 \mathrm{~min}$ at RT with HRP-conjugated secondary antibodies (1:2000, anti-rabbit for $\mathrm{ER} \alpha$ and GPER or anti-mouse for $\mathrm{ER} \beta$, Santa Cruz). Membrane was washed and incubated in Amersham ECL Plus $^{\mathrm{TM}}$ Western Blotting detection reagents (GE Healthcare, UK) for 5 min., and exposed to ECL Hyperfilm (GE Healthcare, UK) and developed. Densitometric analyses of the films were performed using AlphaView software from Alpha Innotec Corporation.

\subsection{Statistics}

The results are presented as median and range, if not otherwise stated. Statistical analysis were performed by ANOVA on ranks (Kruskal-Wallis test) followed by Dunn's test for evaluation of significance. The results are presented as box and whisker plots, with $50 \%$ of the samples within the box. Values with an asterisk are significantly different $(\mathrm{p}<0.05)$ to OvxC.

\section{RESULTS}

\subsection{Uterine Weights}

As an indication of the estrogenic effects of the treatments, the uterine weights were measured. The weights in grams (mean \pm SEM) increased as could be expected from the respective treatment. PPT $(0.205 \mathrm{~g} \pm 0.009 \mathrm{~g})$ and E2 $(0.169 \mathrm{~g} \pm 0.009 \mathrm{~g})$ treatments increased uterine weight significantly as compared to the $\mathrm{OvxC}(0.120 \mathrm{~g} \pm$ $0.007 \mathrm{~g})$ group. Thus, DPN $(0.120 \mathrm{~g} \pm 0.005 \mathrm{~g})$ treatment had no effect on uterine weight.

\subsection{ER $\alpha, E R \beta$ and GPER mRNA Levels}

The uterine ER $\alpha$ mRNA levels, standardized to RPLP0, were decreased after all treatments as compared to OvxC, but reached significance only for PPT and DPN (Figure 1; Table 1). The ER $\beta$ mRNA levels were decreased after

Table 1. Summary of the treatment effects on the mRNA levels and immunohistochemical staining of $\mathrm{ER} \alpha, \mathrm{ER} \beta$, GPER and $\mathrm{Ki}-67$ proteins. Arrows indicate the significant changes found.

\begin{tabular}{|c|c|c|c|}
\hline & E2 & PPT & DPN \\
\hline IHC: $\mathbf{E R} a$ & $\uparrow$ stroma & - & - \\
\hline ER $\alpha$ mRNA & - & $\downarrow$ & $\downarrow$ \\
\hline IHC: ER/ & - & - & $\uparrow$ myometrium \\
\hline ER $\boldsymbol{\beta}$ mRNA & $\downarrow$ & $\downarrow$ & - \\
\hline IHC: GPER & - & - & - \\
\hline GPER mRNA & $\downarrow$ & - & $\downarrow$ \\
\hline IHC: Ki-67 & - & $\uparrow$ stroma + myometrium & - \\
\hline
\end{tabular}

E2 and PPT treatment as compared to the OvxC group, whereas DPN had no effect (Figure 1; Table 1). The GPER mRNA levels decreased after all treatments but reached significance for only E2 and DPN treatments, as compared to the OvxC group (Figure 1; Table 1).

\subsection{ER $\alpha, E R \beta$ and GPER Protein Levels}

A representative western blot of $\mathrm{ER} \alpha, \mathrm{ER} \beta$, GPER and $\beta$-actin is shown in Figure 2. There were no statistically significant differences found between the treatment groups (data not shown), since there was quite a variation between the individual rats. Some of the PPT treated ani-

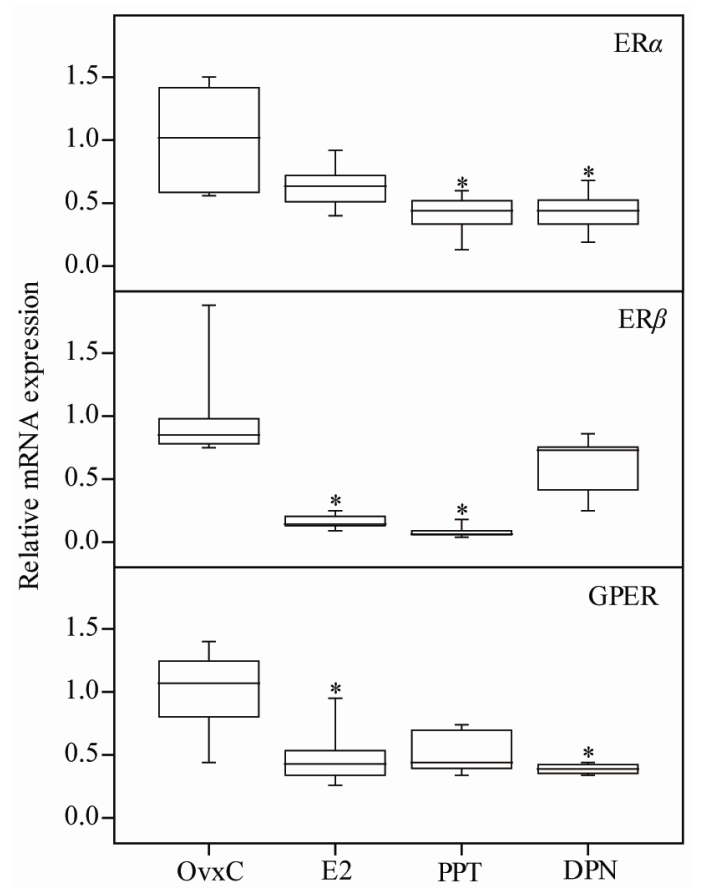

Figure 1. The mRNA levels of $\mathrm{ER} \alpha, \mathrm{ER} \beta$ and GPER in the rat uterus. OvxC = ovariectomized controls; E2, PPT and DPN treated rats; $n=8$ in all groups but DPN where it is 6 . Bars with an asterisk show significant difference to the control group $(\mathrm{OvxC})(\mathrm{p}<$ $0.05)$.

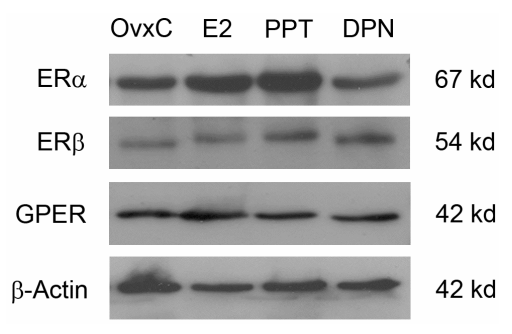

Figure 2. A representative western blot of $\mathrm{ER} \alpha, \mathrm{ER} \beta$ and GPER in uterus from E2, PPT and DPN treated rats and the OvxC control group. $\beta$-Actin was used as loading control. 
mals exposed a stronger ER $\alpha$ band than the OvxC group, but others did not exhibit a difference, why there are no differences when looking at the groups.

\subsection{Immunohistochemical Localization of $\mathrm{ER} \alpha$, ER/ and GPER}

Results from ER $\alpha$ immunostaining in the uterus showed that E2 treatment increased positive immunostaining in the uterine stroma as compared to the OvxC group (Figures 3(A)-(D); Figure 4, top panel; Table 1). No differences were found in the myometrium, luminal and glandular epithelium (Figure 4). $\operatorname{ER} \beta$ immunostaining in the myometrium was increased after DPN treatment, as compared to the OvxC group (Figures 3(E)-(H); Figure 5, bottom panel; Table 1). GPER immunostaining was present in membranes and cytoplasm of all the examined cell types (Figures 3(I)-(L)). GPER was strongly stained in myometrium and blood vessels. However, there were no significant differences in GPER immunoreactivity between the different treatment groups in any of the cell types examined (Figures 3(I)-(L); scoring results not shown).

\subsection{Proliferation}

As assessed by Ki-67 immunostaining and image analysis in the uterus, proliferation was increased in stroma and myometrium after PPT treatment as compared to the OvxC group (Figures 3(M)-(P); Figure 6, top and bottom panels; Table 1). There were no differences in proliferation between the treatment groups in luminal and glandular epithelium (Figure 6).

\section{DISCUSSION}

Estrogens exert biological effects in many tissues. The multitude of estrogen responses matches the widespread distribution of ERs throughout the body, with $\operatorname{ER} \alpha$ expression being the most common isotype in e.g. uterus, pituitary, liver and kidney, while $\operatorname{ER} \beta$ expression is dominating in the ovary and prostate [6]. GPER has been found in a wide variety of tissues, e.g. in reproductive tissues such as uterus and ovary [12]. In accordance with a study on mice [24], PPT and E2 induced uterine weight similarly. Our rats were treated with E2 at a dose of 5 $\mu \mathrm{g} / 250 \mathrm{~g}$ animal and day, while the mice got $0.5 \mu \mathrm{g} / \mathrm{ani}-$ mal and day. Since the mice were 21 days and then weighing approximately $25 \mathrm{~g}$, the dose $/ 100 \mathrm{~g}$ animal should equal ours at $2 \mu \mathrm{g} / 100 \mathrm{~g}$ animal. The PPT dose for the mice was $500 \mu \mathrm{g} / \mathrm{animal}$ and day $(2 \mathrm{mg} / 100 \mathrm{~g}$ mouse), while we gave $1.25 \mathrm{mg} / 250 \mathrm{~g}$ rat and day $(0.5$ $\mathrm{mg} / 100 \mathrm{~g}$ rat). Thus, their PPT dose was higher than ours, but the results were similar. In another study on ovx rats, $75 \mu \mathrm{g}$ PРT (30 $\mu \mathrm{g} / 100 \mathrm{~g}$ rat) increased the uterine weight after 24 hours [25]. Thus, the effect on uterine weight from PPT treatment is achieved with an even lower dose of PPT as well. Furthermore, proliferation was significantly induced after PPT treatment in stroma and myometrium, as compared to controls. In addition, DPN treatment neither increased uterine weight nor proliferation. Consequently, growth and proliferation are mediated primarily by $\mathrm{ER} \alpha$ in the uterus, which confirms previous results [26].

E2 is known to regulate the expression of $\mathrm{ER} \alpha$ at both mRNA and protein levels [27]. An earlier report on ovx rats show that $\mathrm{ER} \alpha \mathrm{mRNA}$ levels were up regulated with no change in protein levels $24 \mathrm{~h}$ after E2 administration [28]. Our data shows that E2 treatment causes no change in the total mRNA and protein levels but up regulates $\mathrm{ER} \alpha$ protein in stroma after $18 \mathrm{~h}$, indicating a time and cell type dependent regulation of the receptor. However, PPT and DPN down regulated ER $\alpha$ expression suggesting both $\operatorname{ER} \alpha$ and $\operatorname{ER} \beta$ to be involved in regulation of $\mathrm{ER} \alpha$ mRNA.

In the E2 and PPT treated groups the $\mathrm{ER} \beta$ mRNA level was down regulated, indicating that $\mathrm{ER} \beta$ expression is regulated via $\mathrm{ER} \alpha$. A previous study showed that total $\mathrm{ER} \beta$ mRNA expression was up regulated after $24 \mathrm{~h}$ of E2 administration [28]. Taken together, it appears that there is an initial down regulation of $\operatorname{ER} \beta$ followed by an increase in the total mRNA expression. Such initial down regulation of the ER mRNA level by E2 injections has been described before in the uteri of ovx rat [29]. The ER mRNA level was thereafter transiently up regulated but decreased again after 72 hrs [29].

Both $\operatorname{ER} \alpha$ and $\operatorname{ER} \beta$ immunostaining is predominantly found in the nuclei, some staining can though be found in the cytoplasm, probably due to the fact that the receptors without ligand are also present outside the nucleus [30, 31]. Since many effects from estrogens are too rapid to be mediated via the nuclear receptors, more and more evidence have suggested the presence of a cytosolic estrogen receptor [31]. GPER is one receptor, which has been described as an estrogen receptor present in membranes and cytoplasm [10].

Interestingly, we observed that both E2 and DPN down regulated GPER mRNA. A recent report shows that E2 down regulates GPER mRNA in MCF-7 cells [32]. Our data suggests that the regulation of GPER mRNA levels is mediated predominantly via $\operatorname{ER} \beta$ in the rat uterus. The discrepancy between down regulated mRNA levels from PCR assays and unaffected protein levels in Western blots could be due to e.g. microRNAs, which are known to regulate processes at the transcriptional and translational level [33]. The mRNA determinations and Western blots are performed in a tissue homogenate, which is different to the immunostaining results obtained by scoring the different tissue parts 


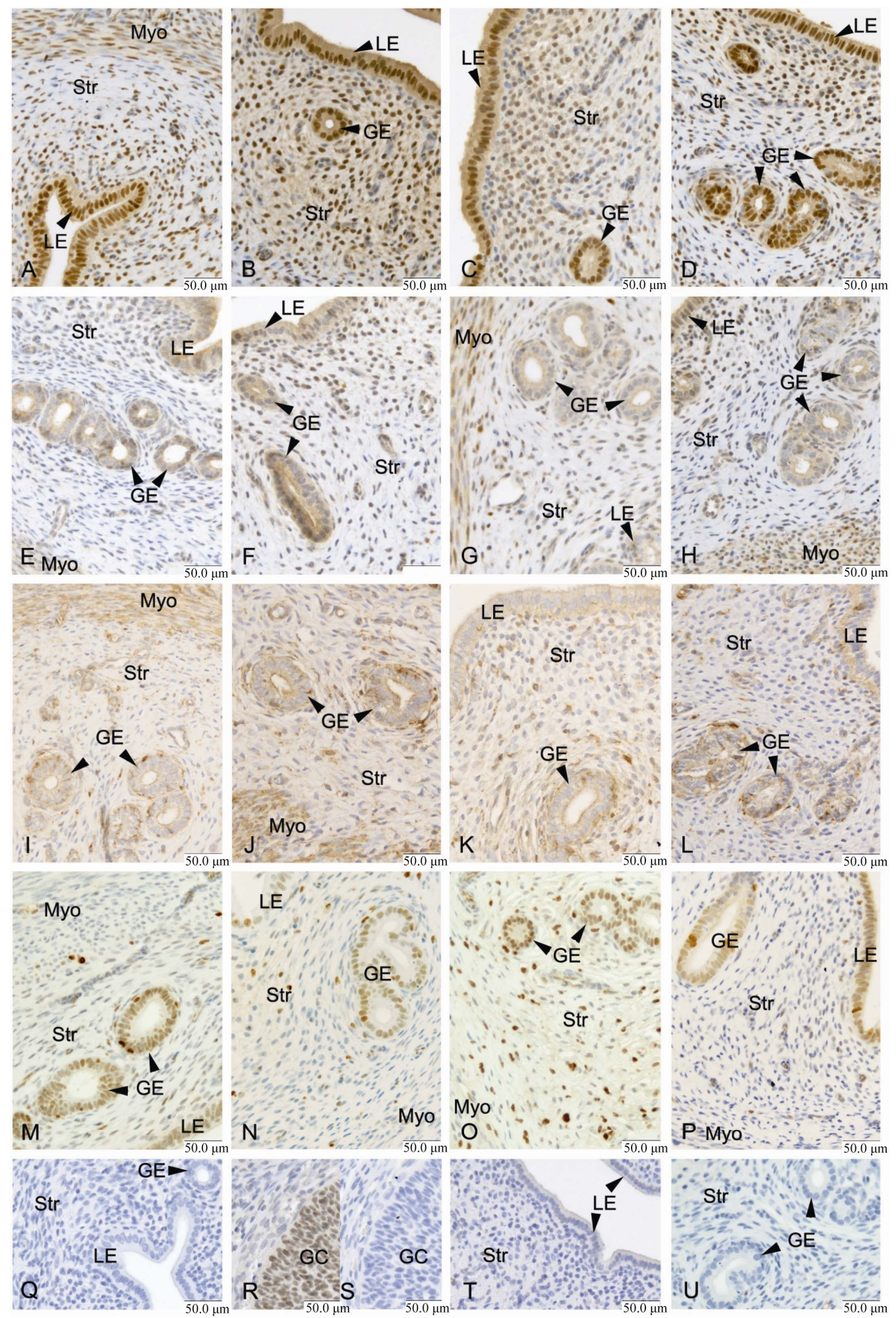

Figure 3. Representative images from immunohistochemistry staining of $E R \alpha(A)-(D), E R \beta$ (E)-(H), GPER (I)-(L), Ki-67 (M)-(P) and control slides (Q)-(U). LE = luminal epithelium, GE = glandular epithelium, $\mathrm{Str}=$ stroma, $\mathrm{Myo}=$ myometrium and $\mathrm{GC}=$ granulosa cells. The bottom panel shows a negative control for ER $\alpha$ IHC in rat uterus (Q), a positive control for ER $\beta$ in rat ovary (R), a negative control for $\mathrm{ER} \beta$ in rat ovary $(\mathrm{S})$, and negative controls for GPER (T) and Ki-67 (U) in rat uterus. The images from the different treatment groups are placed in columns for image (A)-(P); OvxC (Column 1), E2 (Column 2), PPT (Column 3) and DPN (Column 4). Magnification $\times 400$, the bar represents $50 \mu \mathrm{m}$. 


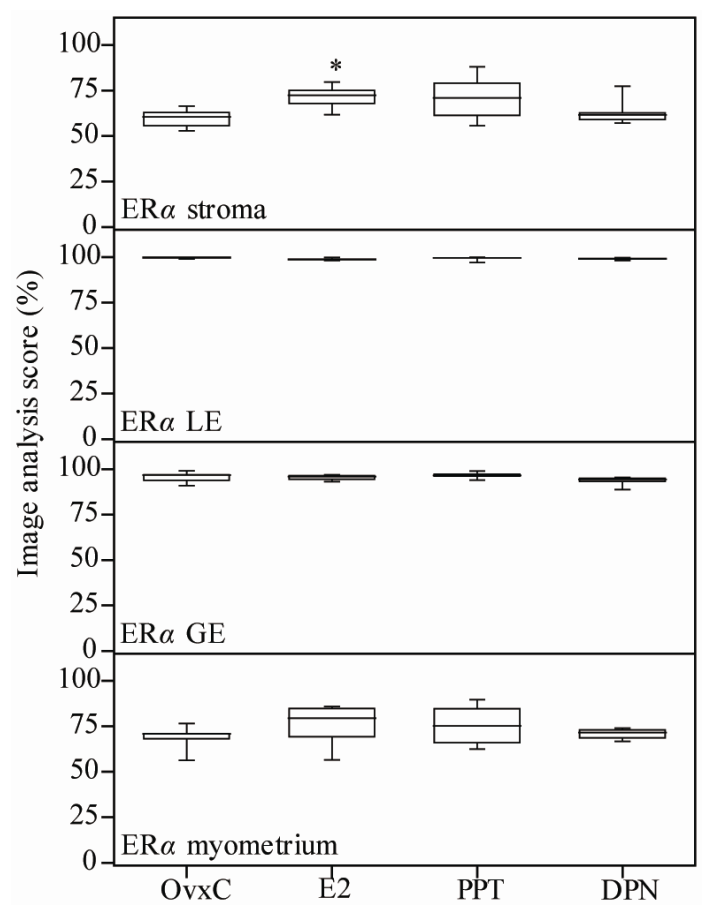

Figure 4. Image analysis scores of $\mathrm{ER} \alpha$ immunostaining. OvxC = ovariectomized controls; E2, PPT and DPN treated rats; $n=8$ in all groups but the DPN where $n=$ 6 . Bars with an asterisk show significant differences to the control group $(\mathrm{OvxC})(\mathrm{p}<0.05)$.

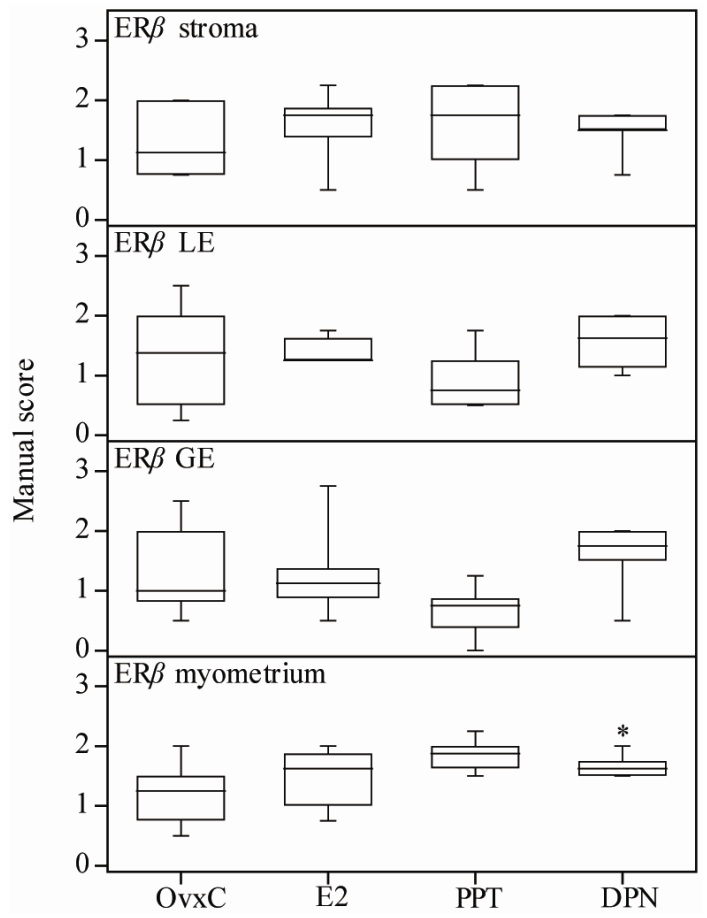

Figure 5. Manual scores of ER $\beta$ immunostaining. OvxC $=$ ovariectomized controls; E2, PPT and DPN treated rats; $n=8$ in all groups but the DPN where $n=6$. Bars with an asterisk show significant differences to the control group $(\mathrm{OvxC})(\mathrm{p}<0.05)$.

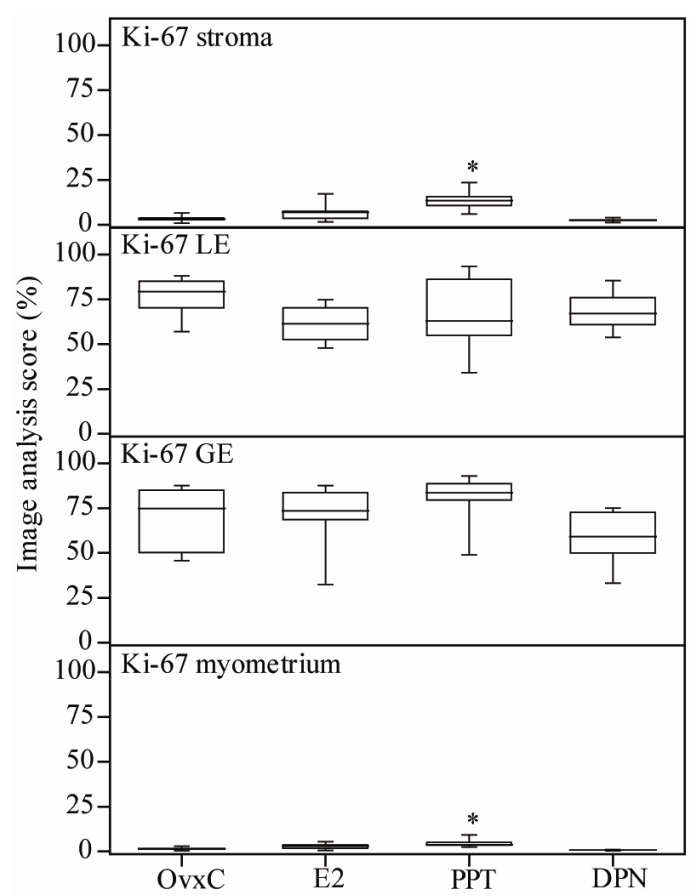

Figure 6. Image analysis scores of the proliferation marker Ki-67 immunostaining. OvxC = ovariectomized controls; E2, PPT and DPN treated rats; $\mathrm{n}=8$ in all groups but the DPN where $\mathrm{n}=6$. Bars with an asterisk show significant differences to the control group $(\mathrm{OvxC})$ $(\mathrm{p}<0.05)$.

individually.

Selective estrogen receptor agonists were shown to affect PR expression in the uterus differently [34]. PR mRNA levels decreased after DPN treatment. Stromal and myometrial immunostaining of PR increased after E2 and PPT treatment, while no effect was found after DPN treatment [34]. E2 was also found to increase ER $\alpha$ immunostaining in the stroma, thus PR and $\mathrm{ER} \alpha$ protein expressions are up regulated in parallel by E2. As opposed to the increased PR immunostaining in myometrium after E2 and PPT treatment, ER $\beta$ immunostaining was increased only after DPN treatment. Thus, PR and ER $\beta$ expression might counteract each other, why PR was found increased only when $\operatorname{ER} \beta$ was not, and vice versa.

In conclusion, our study confirms that uterine growth and proliferation is mediated via $\mathrm{ER} \alpha$. ER $\alpha$ activation down regulates ER $\beta$ mRNA expression in the ovx rat uterus, while $\operatorname{ER} \beta$ binding mediates down regulation of GPER mRNA levels.

\section{ACKNOWLEDGEMENTS}

This study received financial support from The Swedish Research Council (project 20137), the regional agreement on medical training and clinical research (ALF) between Stockholm County Council and Karolinska Institutet, and Karolinska Institutet. C. S. Blesson was fi- 
nanced by a grant for the Swedish Institute and received support from Kronprinsessan Lovisas förening and Sällskapet Barnavård.

\section{REFERENCES}

[1] Kuiper, G.G., Enmark, E., Pelto-Huikko, M., Nilsson, S. and Gustafsson, J.A. (1996) Cloning of a novel receptor expressed in rat prostate and ovary. Proceedings of the National Academy of Sciences of USA, 93, 5925-5930. doi:10.1073/pnas.93.12.5925

[2] Green, S., Walter, P., Kumar, V., Krust, A., Bornert, J.M., Argos P. and Chambon, P. (1986) Human oestrogen receptor cDNA: Sequence, expression and homology to verb-A. Nature, 320, 134-139. doi:10.1038/320134a0

[3] Mosselman, S., Polman, J. and Dijkema, R. (1996) ER beta: Identification and characterization of a novel human estrogen receptor. FEBS Letters, 392, 49-53. doi:10.1016/0014-5793(96)00782-X

[4] Tremblay, G.B., Tremblay, A., Copeland, N.G., Gilbert, D.J., Jenkins, N.A., Labrie, F. and Giguere, V. (1997) Cloning, chromosomal localization, and functional analysis of the murine estrogen receptor beta. Molecular Endocrinology, 11, 353-365. doi:10.1210/me.11.3.353

[5] Pettersson, K., Grandien, K., Kuiper, G.G. and Gustafsson, J.A. (1997) Mouse estrogen receptor beta forms estrogen response element-binding heterodimers with estrogen receptor alpha. Molecular Endocrinology, 11, 1486-1496. doi:10.1210/me.11.10.1486

[6] Kuiper, G.G., Carlsson, B., Grandien, K., Enmark, E., Haggblad, J., Nilsson, S. and Gustafsson, J.A. (1997) Comparison of the ligand binding specificity and transcript tissue distribution of estrogen receptors alpha and beta. Endocrinology, 138, 863-870. doi:10.1210/en.138.3.863

[7] Clark, B.F. (1971) The effects of oestrogen and progesterone on uterine cell division and epithelial morphology in spayed, adrenalectomized rats. Journal of Endocrinology, 50, 527-528. doi:10.1677/joe.0.0500527

[8] Tachi, C., Tachi, S. and Lindner, H.R. (1972) Modification by progesterone of oestradiol-induced cell proliferation, RNA synthesis and oestradiol distribution in the rat uterus. Journal of Reproduction and Fertility, 31, 59-76. doi:10.1530/jrf.0.0310059

[9] Cooke, P.S., Buchanan, D.L., Lubahn, D.B. and Cunha, G.R. (1998) Mechanism of estrogen action: Lessons from the estrogen receptor-alpha knockout mouse. Biology of Reproduction, 59, 470-475. doi:10.1095/biolreprod59.3.470

[10] Filardo, E.J., Quinn, J.A., Frackelton, A.R., Jr. and Bland, K.I. (2002) Estrogen action via the $G$ protein-coupled receptor, GPR30: Stimulation of adenylyl cyclase and cAMPmediated attenuation of the epidermal growth factor receptor-to-MAPK signaling axis. Molecular endocrinology, 16, 70-84. doi:10.1210/me.16.1.70

[11] Revankar, C.M., Cimino, D.F., Sklar, L.A., Arterburn, J.B. and Prossnitz, E.R. (2005) A transmembrane intracellular estrogen receptor mediates rapid cell signaling. Science, 307, 1625-1630. doi:10.1126/science. 1106943
[12] Olde, B. and Leeb-Lundberg, L.M. (2009) GPR30/GPER1: Searching for a role in estrogen physiology. Trends in Endocrinology \& Metabolism, 20, 409-416. doi:10.1016/i.tem.2009.04.006

[13] Martensson, U.E., Salehi, S.A., Windahl, S., Gomez, M.F., Sward, K., Daszkiewicz-Nilsson, J., Wendt, A., Andersson, N., Hellstrand, P., Grande, P.O., Owman, C., Rosen, C.J., Adamo, M.L., Lundquist, I., Rorsman, P., Nilsson, B.O., Ohlsson, C., Olde, B. and Leeb-Lundberg, L.M (2009) Deletion of the G protein-coupled receptor 30 impairs glucose tolerance, reduces bone growth, increases blood pressure, and eliminates estradiol-stimulated insulin release in female mice. Endocrinology, 150, 687-698. doi:10.1210/en.2008-0623

[14] Thomas, P., Pang, Y., Filardo, E.J. and Dong, J. (2005) Identity of an estrogen membrane receptor coupled to a $\mathrm{G}$ protein in human breast cancer cells. Endocrinology, 146, 624-632. doi:10.1210/en.2004-1064

[15] Prossnitz, E.R. and Barton, M., (2011) The G-proteincoupled estrogen receptor GPER in health and disease. Nature Reviews Endocrinology, 7, 715-726. doi:10.1038/nrendo.2011.122

[16] Windahl, S.H., Andersson, N., Chagin, A.S., Martensson, U.E., Carlsten, H., Olde, B., Swanson, C., Moverare-Skrtic, S., Savendahl, L., Lagerquist, M.K., Leeb-Lundberg, L.M. and Ohlsson, C. (2009) The role of the G protein-coupled receptor GPR30 in the effects of estrogen in ovariectomized mice. American Journal of Physiology-Endocrinology and Metabolism, 296, E490-E496. doi:10.1152/ajpendo.90691.2008

[17] Otto, C., I. Fuchs, G. Kauselmann, H. Kern, B. Zevnik, P. Andreasen, G. Schwarz, H. Altmann, M. Klewer, M. Schoor, R. Vonk, and K.H. Fritzemeier. (2009) GPR30 does not mediate estrogenic responses in reproductive organs in mice. Biology of Reproduction, 80, 34-41. doi:10.1095/biolreprod.108.071175

[18] Smith, H.O., Leslie, K.K., Singh, M., Qualls, C.R., Revankar, C.M., Joste, N.E. and Prossnitz, E.R. (2007) GPR30: A novel indicator of poor survival for endometrial carcinoma. American Journal of Obstetrics and Gynecology, 196, e1-e9, e9-e11. doi:10.1016/j.ajog.2007.01.004

[19] Gao, F., Ma, X., Ostmann, A.B. and Das, S.K. (2011) GPR30 activation opposes estrogen-dependent uterine growth via inhibition of stromal ERK1/2 and estrogen receptor alpha (ERalpha) phosphorylation signals. Endocrinology, 152, 1434-1447. doi:10.1210/en.2010-1368

[20] Kraichely, D.M., Sun, J., Katzenellenbogen, J.A. and Katzenellenbogen, B.S. (2000) Conformational changes and coactivator recruitment by novel ligands for estrogen receptor-alpha and estrogen receptor-beta: Correlations with biological character and distinct differences among SRC coactivator family members. Endocrinology, 141, 35343545. doi:10.1210/en.141.10.3534

[21] Stauffer, S.R., Coletta, C.J., Tedesco, R., Nishiguchi, G., Carlson, K., Sun, J., Katzenellenbogen, B.S. and Katzenellenbogen, J.A. (2000) Pyrazole ligands: Structure-affinity/activity relationships and estrogen receptor-alpha-selective agonists. Journal of Medicinal Chemistry, 43, 4934- 
4947. doi:10.1021/jm000170m

[22] Meyers, M.J., Sun, J., Carlson, K.E., Marriner, G.A., Katzenellenbogen, B.S. and Katzenellenbogen, J.A. (2001) Estrogen receptor-beta potency-selective ligands: Structure-activity relationship studies of diarylpropionitriles and their acetylene and polar analogues. Journal of Medicinal Chemistry, 44, 4230-4251. doi:10.1021/im010254a

[23] Lowry, O.H., Rosebrough, N.J., Farr, A.L. and Randall, R.J. (1951) Protein measurement with the Folin phenol reagent. Journal of Biological Chemistry, 193, 265-275.

[24] Frasor, J., Barnett, D.H., Danes, J.M., Hess, R., Parlow, A.F. and Katzenellenbogen, B.S. (2003) Response-specific and ligand dose-dependent modulation of estrogen receptor (ER) alpha activity by ERbeta in the uterus. Endocrinology, 144, 3159-3166. doi:10.1210/en.2002-0143

[25] Santollo, J. and Eckel, L.A. (2009) Effect of a putative ERalpha antagonist, MPP, on food intake in cycling and ovariectomized rats. Physiology \& Behavior, 97, 193-198. doi:10.1016/j.physbeh.2009.02.021

[26] Lindberg, M.K., Weihua, Z., Andersson, N., Moverare, S., Gao, H., Vidal, O., Erlandsson, M., Windahl, S., Andersson, G., Lubahn, D.B., Carlsten, H., Dahlman-Wright, K., Gustafsson, J.A. and Ohlsson., C. (2002) Estrogen receptor specificity for the effects of estrogen in ovariectomized mice. Journal of Endocrinology, 174, 167-178. doi:10.1677/joe.0.1740167

[27] Ing, N.H. (1995) The steroid hormone receptor superfamily: molecular mechanisms of action. In: Weintraub, B.D., Ed., Molecular Endocrinology: Basic Concepts and Clinical Correlations, Raven Press, New York, 195-216.
[28] Wang, H., Masironi, B., Eriksson, H. and Sahlin, L. (1999) A comparative study of estrogen receptors alpha and beta in the rat uterus. Biology of Reproduction, 61, 955-964. doi:10.1095/biolreprod61.4.955

[29] Sahlin, L., Norstedt, G. and Eriksson, H. (1994) Estrogen regulation of the estrogen receptor and insulinlike growth factor-I in the rat uterus: A potential coupling between effects of estrogen and IGF-I. Steroids, 59, 421-430. doi:10.1016/0039-128X(94)90011-6

[30] Parker, M.G. (1995) Structure and function of estrogen receptors. Vitamins \& Hormones, 51, 267-287. doi:10.1016/S0083-6729(08)61041-9

[31] Bjornstrom, L. and Sjoberg, M. (2005) Mechanisms of estrogen receptor signaling: Convergence of genomic and nongenomic actions on target genes. Molecular Endocrinology, 19, 833-842. doi:10.1210/me.2004-0486

[32] Ariazi, E.A., Brailoiu, E., Yerrum, S., Shupp, H.A., Slifker, M.J., Cunliffe, H.E., Black, M.A., Donato, A.L., Arterburn, J.B., Oprea, T.I., Prossnitz, E.R., Dun, N.J. and Jordan, V.C. (2010) The G protein-coupled receptor GPR30 inhibits proliferation of estrogen receptor-positive breast cancer cells. Cancer research, 70, 1184-1194. doi:10.1158/0008-5472.CAN-09-3068

[33] Gotte, M. (2010) MicroRNAs in breast cancer pathogenesis. Minerva Ginecologica, 62, 559-571.

[34] Sahlin, L., Masironi, B., Akerberg, S. and Eriksson, H. (2006) Tissue- and hormone-dependent progesterone receptor distribution in the rat uterus. Reproductive Biology and Endocrinology, 4, 47. doi:10.1186/1477-7827-4-47 